\title{
CORRESPONDENCE
}

\section{Unsöld on Einstein}

$\mathrm{S}_{\mathrm{IR}}$ - We find the statements regarding Einstein made by Professor Unsolld (see Nature 16 April, p.535) outrageous and would like to express our strong disagreement. This is particularly important to us now since, in a later letter to Nature (4 June, p.374),

Professor Unsöld implies that the physics department of the University of Marburg might essentially share his opinion because nobody took issue during the discussion following his colloquium in April 1980.

At the end of his colloquium, Professor Unsöld made various remarks regarding the responsibility of scientists for the application of their discoveries and, in this context, mentioned such names as Einstein and Haber. Some members of the audience had the impression that in so doing he was attempting to compare the responsibility of Hitler and the Nazi leaders for the holocaust with the responsibility of Einstein for the atomic bomb.

In fact, this point was not further discussed after his talk, and one can easily guess why. The title of the talk was "Evolution of cosmic, biological and mental structures", and the remarks concerning Einstein and his relation to the atomic bomb came at the end of a very long talk when Professor Unsöld had by far exceeded the time allotted. The tired audience probably considered these remarks a slip of the tongue by the speaker. However, Professor Unsöld in Physikalische Blätter greatly elaborates on his opinion on the responsibility of Einstein. Therefore, we find it imperative to protest at his views.

In his contribution to Physikalische Blätter, Professor Unsöld attempts to remove Einstein from the allegedly unwarranted pedestal on which he was placed by some speakers at the meetings during the Einstein centenary. He also tries to revise opinion on the scientific merits of Einstein. It is, of course, quite possible that a judgement on Einstein's achievements in physics might lead to conflicting views among physicists. We dare say, however, that Professor Unsöld's evaluation of the great discoveries of Einstein is unacceptable. However, this is not the point in question.

Professor Unsöld sought to prove his theory that an ever wider gap appears between the

\section{Nabi - A life}

SIR - I would like to make some corrections and additions regarding Isidore Nabi, now that his cat has partly emerged from its bag (Nature 3 September, p.2).

The committee called Nabi was formed in the early $1960 \mathrm{~s}$, with a programme analogous to, but much less ambitious than, that of the French mathematician Nicholas Bourbaki. Nabi's initial consultants were Richard I.evins (not Lester), then at the University of Puerto Rico, Richard Lewontin, then at the University of Rochester, the late Robert MacArthur, then at the University of Pennsylvania, and myself, then at the American Museum of Natural History. Three of us later moved to the University of Chicago, which had no role initially. 1 believe that Edward O. Wilson, then as now at Harvard University, became peripherally associated for a while.

While scientific work can ordinarily stand intellectual capacities of physicists to obtain far-reaching knowledge and their moral qualities, which would guarantee that they use their knowledge in a responsible way. He makes the physicists solely responsible.

Einstein was the example chosen to prove this theory. We believe that this theory is disputable in principle. Responsibility for the achievements of science does not rest only with the physicists, but concerns the entire human community. Professor Unsöld attempts to present Einstein as a person of dubious morals and to show that it was quite consistent with Einstein's nature that he should make the "criminal" (in Professor Unsöld's view) decision to write a letter to Roosevelt pointing out the possibility of constructing the atomic bomb. The subsequent use of this bomb at Hiroshima and Nagasaki appears to him to be the work of Einstein. He then compares the "criminal" behaviour of Einstein with the "highly moral" behaviour of German physicists who, despite their sufferings during the Hitler regime, managed to "do some teaching and to safeguard the libraries".

We find it unthinkable that, thirty-five years after the greatest crime in history, a German physicist dares to accuse a man who had to flee Germany to save his life, of criminal behaviour, when indeed he was obviously attempting to help mankind defend itself against the perpetrators of this very crime.

As members of the physics faculty of the University of Marburg, we consider Professor Unsöld's remarks totally unacceptable, and do not wish to condone them by remaining silent. We believe that it is the duty of every German citizen to remember the recent historical events. The written and oral statements of Professor Unsöld certainly do not demonstrate this. Moreover, the seeming acceptance of his statement by some people suggests that some German physicists are no longer conscious of this shameful past. We hope that this

"discussion" about Einstein will contribute to an improvement in this direction.

Hol.ger Neumianin, Ol.af Mri.sheiater, WoI.FGANG ADAMCZAK, REINHARD ECKHORN, Jurgen Al.tmann, Wol fiangi Bayer, Ral.f Beckmann, Norbert Stei.te, REINHARD Branit, LUdWIC; SCHWEITZER, Gustav Sauer, Petek Thomas Philipps-University of Marburg, FRG

on its own, I agree that political statements such as those recently published in Nabi's name should be evaluated with knowledge of their author. Indeed, Nabi's consultants are politically diverse. While I am not a sociobiologist, my political opinions do not resemble those of Levins and 1.ewontin; neither did MacArthur's. However, this did not affect our collaborations.

Our consultation with Nabi was scientific, intended to further an analytic and unified approach to evolutionary biology, an approach which was then very unfashionable. Nabi's book, however, was only partly written when circumstances caused its abortion.

Nabi has survived, mostly, past his $71 \mathrm{st}$ birthday (on the same date as Mendel's), and his service in Czechoslovakia for the US Office of Strategic Services during World War II, for which he received US citizenship, was perhaps more dangerous than the public eye.

\section{Councils of dispare}

SIR - During the past 12 months or so I have submitted about a dozen papers to various journals and about a dozen grant applications to various grant awarding bodies. I have also refereed about a dozen papers and a rather smaller number of grant applications.

I am sorry to say that not all my own submissions have been 100 per cent successful on their first attempi. Nevertheless, from the journals I usually receive copies of the referees' reports (often containing helpful suggestions) together with an overall assessment from the editorial office. From the research councils, however, almost no information at all is produced about reasons for rejection.

The curious thing is that as a referee I spend about as much time refereeing a grant application as a paper and submit reports of roughly comparable length. I know that the secretaries who service the research council committees have to prepare minutes. Why is one group prepared to be so constructive whereas the other is so negative? I do hope it is nothing to do with the fact that journals exist at least partly to make a profit (either for shareholders or for the members of some scientific society) whereas the research councils lack such an aim!

Al.AN D.B. Mal.COI M

Biochemistry Department,

St Mary's Hospital Medical School,

London, UK

\section{Book learning}

SiR - The recent letters from Andrew Brooks (Nature 7 May, p.7) and Robert Campbell (Nature 28 May, p.278) about the problems of retrieving information do not touch on a much more serious problem - the need for librarians with some subject expertise. Expecting students and researchers to learn about as well as maintain currency in both the intricacies of data base searching and the wide variety of printed data sources is simply unrealistic.

Asking for help is obviously de rigueur for efficient use of libraries. Are libraries meeting this challenge by recruiting staff members with some subject expertise, especially in the sciences?

DANA L. ROTH

Robert A. Millikan Memorial Library, California Institute of Technology, Pasadena, USA

\section{Stirling service}

Slk - The general features of the cuts recently imposed on the university system by the University Grants Committee are now widely known. What is less well known is how arbitrary and inequitablc some of those cuts appear to be. At the University of Stirling, the largest cuts (around 35 per cent) are to be in the sciences and although the physical sciences are to be given some priority, it is beyond question that our own department will suffer in terms of reduced resources. We would like to bring to the attention of the scientific community the inequity of what is proposed.

The Chemistry Department at Stirling University is one of the smallest university chemistry departments in Britain, and the 


\section{CORRESPONDENCE}

\section{Continued from page 422}

smallest in Scotland. Founded by Professor Ronnie Bell FRS, in 1967, it survived the loss of Professor Willie Parker, to continue as a well-known, well-equipped, highly cost effective unit in one of Britain's modern universities.

Faced with a considerable reduction in resources, we have compared our performance across a broad spectrum of activities with other chemistry departments in Scotland.

(1) We have the smallest number of academic staff.

(2) We have produced, over the last eight years, the largest number of publications per member of staff.

(3) We are ranked second in terms of the value of SRC grants currently in operation per member of staff. At the last round of SRC grant considerations, all five of the department's applications were funded by the Chemistry Committee.

(4) We have a student/staff ratio of 8.6/1 which is the average for Scotland.

(5) Our entrance standards are about average for Scottish universities, and chemistry applications have increased by 37 per cent in 1981 over 1980 (which in turn were higher than previously).

We, therefore, find ourselves questioning the actions of the University Grants Committee which appear to be inconsistent with criteria they themselves have outlined, and which, if put into effect at Stirling, will put our future at risk.

R.M. Ci.aY, J.M.G. CowIE, B.G. CoX,

R.W. HaY, H. MASKIH.I., P. MurRaY-RUST,

A.E.A. Porter, F.G. RidDei.I.,

J.S. Roberts, W.V. StieeI.E, I.C. WAi.kek Chemistry Department,

University of Stirling, UK

\section{Academics' year}

SiR - G. W. Brindley's suggestion (Nature 27 August, p.791) of a 9-month academic year contract as the solution to the financial crisis in UK universities is ludicrous. In the United States, in actual practice, academics are paid as much for a nominal 9-month academic year as for a 12-month year, the only difference being that they are now free to pay themselves an additional salary from their research grant.

The 9-month academic year is thus nothing more than a convenient fiction that enables principal investigators to divert research funds into their own pockets, effectively diminishing total support for research, while enhancing their own standard of living.

ROBERT J. YAes

Memorial Sloan-Kettering Cancer Center, New York, USA

\section{Effluent safety limits}

SIR - Day and Cross' have recently reported very interesting data on the in situ production of ${ }^{241} \mathrm{Am}$ from its parent ${ }^{24 I} \mathrm{Pu}$ in the Irish Sea which receives radioactive effluents from the Windscale nuclear fuel reprocessing facility. When authorizing the quantities of radioactivity which may be discharged by Windscale, the United Kingdom regulating agencies [Department of the Environment, Ministry of Agriculture, Fisheries and Food (DOE/MAFF)] have published only limited information ${ }^{2,3}$ on the environmental ingrowth of the radiotoxic alpha-emitter ${ }^{241} \mathrm{Am}$ from the unrestricted discharges of ${ }^{241} \mathrm{Pu}$. The publication of much more comprehensive data and calculations by Day and Cross show that the annual in situ formation of ${ }^{241}$ Am has been 480 per cent, 240 per cent and 265 per cent of those quantities of ${ }^{241}$ Am discharged directly from Windscale in 1977, 1978 and 1979 respectively. Their calculations show further that if the recent rates of ${ }^{241} \mathrm{Pu}$ discharge are maintained, the in situ ${ }^{241} \mathrm{Am}$ production will continue to rise from $\sim 600 \mathrm{Ci}$ per year at present to achieve a steady state situation of $\sim 1,300 \mathrm{Ci}$ per year ingrowth after the turn of the century.

Although the DOE/MAFF-authorized maximum direct discharge limit of alpha activity to the Irish $\mathrm{Sea}$ is $6,000 \mathrm{Ci}$ per year (by the Windscale pipeline) it is not clear from what has been published whether the DOE/MAFF limit includes the fact that there is an increasing ingrowth of ${ }^{241} \mathrm{Am}$ which under steady state conditions will generate a further $\sim 1,300 \mathrm{Ci}$ of alpha activity per year. In other words, does the radiological assessment lead to the definition of the safe total annual input as being $6,000 \mathrm{Ci}$ or 7,300 $\mathrm{Ci}$ alpha activity? If the total acceptable annual input is thought to be $6,000 \mathrm{Ci}$, then the pipeline alpha discharge limit should be continuously revised downward to $4,700 \mathrm{Ci}$ per year if similar ${ }^{241} \mathrm{Pu}$ discharges are to be maintained.

The authorized annual alpha discharge limit set for the Windscale pipeline was raised to $6,000 \mathrm{Ci}$ in 1970 . Since then some significant data have been reported on the behaviour of plutonium and americium isotopes in this coastal environment. (1) These substances are now known to be accumulated very effectively in local sediments around Windscale ${ }^{2,4}$, and their dispersion and dilution by seawater are much less than was previously expected. (2) It has been shown that the transport of these radionuclides within these sediments is slow ${ }^{5,6}$ (3) The ingrowth of ${ }^{241} \mathrm{Am}$ in the sediments is an increasingly substantial proportion of the alpha activity ${ }^{\text {. }}$.

The result of these effects is that the Windscale alpha activity is not widely diluted but is concentrated in a small portion of the environment. Day and Cross's data and these other observations should thus be taken into account in the regulation of the discharges of alpha activity and ${ }^{241} \mathrm{Pu}$ from Windscale in the future. It is interesting and probably optimistic to note that British Nuclear Fuels Limited reduced the unrestricted discharge of ${ }^{241} \mathrm{Pu}$ from Windscale by 49 per cent in $1980^{7}$.

S.R. Aston

Department of Environmental Sciences, University of Lancaster, UK

1. Day. J.P. \& Cress, J.E. Nature 292, 43-45 (1981).

2. Hetheringlon. J.A., Jefferies, D.F., Alitchell, N.T. Pentreath, R.J. \& Woodhead. D.S. Int. Symp. on Transuranic Nuclides in the Marine Environment (IAEA. Vicnna, 1976).

3. Pentreath, R.J. Int. Symp. on the Impacts of Radionuclide Releases into the Marine Environment (IAEA Vienna, 1980).

4. Livingston, H.D. \& Bowen, V.T. Nature 269, 586 (1981).

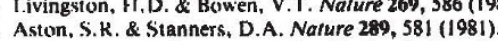

6. Aston, S.K. \& Stanners, D.A. Envir. Pollut. Ser. B (in the press)

7. British Nuctear Fucls I.imited Annual Report on Rodio active Discharges and Monitoring of the Environment 1980 (BNirI, Risley, 1981).

\section{Notes from a Recorder}

SIR - All seventeen Recorders must have been flattered by the comment (Nature 3 September, p.1,) that they provide "virtually the only intellectual continuity" in the British Association for the Advancement of Science. Indeed, it makes a weicome change from being mistaken for either a member of the judiciary or a musical instrument.

However, some of the problems you outline which face the British Association are being tackled.

To even the most casual observer, the bimodality of the age structure of BA must be apparent. Young people - British Association Young Scientists (BAYS) - attend and so too do scientists of more mature years. But scientists of middle years go to specialist conferences (if they can obtain funding at all). Although this latter group may be persuaded to break into family holidays to give a nonexpenses paid paper, they are often unable to stay the whole week. And the meeting is the poorer. Closer links with relevant professional and learned societies and planning of joint lecture sessions might bring back these scientists to the BA. They may, of course, not wish to come. It is often more comfortable to be surrounded by a coterie using familiar, insulating jargon.

If this approach is only partially successful, the BA may yet attract this middle age range group by another means. Provision of nursery school facilities and programmes for the whole family on lines well established at many university summer schools should prove more attractive to scientists with young families. A start on this scheme will be made by the Programme Planning Committee for implementation at Liverpool in 1982; by 1983 at Sussex a whole range of activities for family groups should be available.

All the topics listed in the Nature leading article as worthy of BA consideration have been aired in the last four years, one, genetic engineering, in my own Section D (zoology) last year at Salford. I would suggest also that the BA is the right forum for popularizing science. It is certainly not easy, especially with the advent of superb scientific documentaries on television; both natural history museums and the BA have learnt this to their cost.

However, to see the light of recognition dawning on the faces of young audiences when excellent speakers are putting across difficult concepts leads one to suppose that the BA can, and does, popularize rather well. Excellent proof of this was available at the Section D session at York this year on predator/prey relationships.

Perhaps where we do need to adjust our sights is in reviving the feeling of excitement generated by the announcement of discoveries and breakthroughs at the annual meeting. These are notoriously difficult to produce to order, but not impossible to stage-manage provided one chooses an innovative and productive section president.

TONY FINCHAM

(Chairman of Recorders Committee)

British Museum (Natural History),

London SW7, UK 